\title{
STEM Etkinliklerinin Öğrencilerin STEM Alanlarına Yönelik Tutumuna ve Fene Yönelik Motivasyonlarına Etkisi a
}

\author{
Mustafa Şanlıb, c, Demet Hatice Somuncuoğlu Özerbaş ${ }^{\mathrm{d}}$
}

Özet

$\mathrm{Bu}$ araştırmada, ortaokul öğrencilerine uygulanan STEM (Science, Technology, Engineering, Mathematic) etkinliklerinin, öğrencilerin STEM alanına yönelik tutumlarına ve fene yönelik motivasyonlarına etkisi incelenmiştir. Araştırma deneme öncesi deneysel desenlerden tek grup ön-son test modelinde yürütülmüş ve örneklemi Ankara ilindeki bir özel ortaokulda eğitim alan 70 öğrenciden oluşturmaktadır. Öğrencilerden elde edilen veriler, "STEM Eğitimine Yönelik Tutum Ölçeği" ve "Fen Öğrenmeye Yönelik Motivasyon Ölçeği" ile alınmıştır. Araştırma verileri örneklemler t-testi ve Wilcoxon işaretli sıralar testi xile analiz edilmiştir. Araştırma bulguları; STEM eğitiminden sonra ğrencilerin STEM alanlarına yönelik tutumlarında genel olarak anlamlı bir değişim olmadığı sonucuna ulaşılmıştır. Ayrıca uygulanan STEM eğitiminin, öğrencilerin araştırma yapma ve katılıma yönelik motivasyonu üzerinde olumlu bir etkiye sahip olduğu, ancak işbirlikli çalışma, performans ve iletişime yönelik motivasyonunu anlamlı olarak değişmediği görülmüştür. STEM eğitimi öğrencilerin fen yönelik genel motivasyonunu olumlu bir etkilemiştir. Bu etki küçük düzeydedir.
Anahtar Kelimeler

STEM Eğitimi

Motivasyon

Tutum

Bilim Eğitimi

Makale Hakkında

Geliş Tarihi: 02.03.2021

Kabul Tarihi: 24.09.2021

Doi: $10.18026 /$ cbayarsos. 889816

\section{The Effect of STEM Activities On Students' Attitudes Towards STEM Fields and Science Motivations}

\begin{abstract}
In this research, it is aimed to investigate the effects of STEM applied to middle school students on motivation towards science. The sample of the study, which was carried out regarding pre-experimental design in a single group pre-test and post-test model, was composed of 70 students studying in a private middle school in Ankara. The attitude scale towards STEM Education and the motivation scale for science learning was used to collect data. The data obtained from the study were analyzed with related samples t-test and Wilcoxon signed-rank test. The findings of the research show that STEM education was not generally effective on the attitude. STEM education had a positive effect on the students' motivation to do research and participation but the motivation for cooperative work, performance, communication did not change significantly after STEM education. STEM education positively affected students' general motivation towards science. This effect is small.
\end{abstract}

Keywords

STEM Education

Motivation

Science Learning

Attitude

\section{About Article}

Received: 02.03.2020

Accepted: 24.09.2021

Doi: $10.18026 /$ cbayarsos. 889816

b İletişim Yazarı: sanlimustafa@gmail.com

c Eğitim Yöneticisi, ORCID ID: 0000-0001-8116-8742 .

d Prof. Dr., Gazi Üniversitesi, Gazi Eğitim Fakültesi, ORCID ID: 0000-0002-2050-1182. 


\section{Giriş}

Eğitim bireylerin toplum içinde etkin bir şekilde yer almalarını sağlayacak bilgi, beceri ve yetenekleri kazanmalarını amaçlamaktadır. Öğrenme öğretme süreçleri bu amacın gerçekleşmesinde büyük bir rol oynamaktadır. Yapılandırmacı yaklaşım gibi öğrenciyi merkeze alan anlayışların bu süreçlerde büyük değişimlere neden olduğu görülmektedir. Bu değişimlere bütünsel olarak bakıldığında kazandırılmak istenenin; endüstriye yönelik iş gücü, hayat boyu öğrenmeyi ilke edinecek kültürel okuryazarlık ve eleştirel düşünme becerisine sahip bireyler yetiştirmek olduğu ifade edilebilir. Buradan hareketle, hedeflerin doğru belirlenerek öğrenme standartlarının oluşturulması gerekir. (Özden, 2005). Çağın ihtiyacı olan "insan gücü" kavramının yerini, "insan gücü ve niteliği" kavramı almakta ve buna bağlı olarak bireylerin 21.y.y. becerilerine sahip olma durumları sorgulanır duruma gelmiştir. Yeni yetişen nesilden, sadece bir alanda bilgi ve deneyim sahibi olmaları yerine, iletişim, sosyal, öz-yönetim, problem çözme v.b. becerileri geliştirmiş, disiplinler arası çalışmayı ilke edinen merak eden, sorgulayan ve keşfeden bireyler olmaları beklenmektedir (Koştur, 2017). Eğitim sistemleri içindeki müfredatların, kullanılan yöntem ve öğretim stratejilerinin bilimsel bilgi, bilimsel sorgulama ve mühendislik tasarım süreçleriyle bütünleştirilmesi büyük öneme sahiptir (Buyruk ve Korkmaz, 2016). Eğitim tarihine bakıldığında bu özellikler, Dewey (18591952), Kilpatrick (1871-1965), Kerschensteiner (1854-1932), Decroly (1871-1932), Ferriere (1879-1960), Freinet (1896-1966), Gaudig (1860-1923) gibi önde gelen temsilcilerin olduğu iş eğitimi yaklaşımlarında görülmektedir. Çünkü iş eğitimi, öğrencinin öğrenirken faal olma ve yaparak yaşayarak öğrenme prensibinin yani öğrenme sürecinde aktif olmasının onun zihnini geliştireceği anlayışını desteklemiştir. (Aytaç, 1976) Yine bu akımın etkisi ile ilkokul programlarında mutfak, işlik, arılık, uygulama bahçesi gibi çalışma yerleri öngöruilmüş, bu suretle okulda çocuğa geniş ölçüde yaratma, iş ve etkinlik imkanı sağlanmaya çalışılmıştır (Taşdemirci, 1984).

Keser(1987) İş eğitiminin detaylarına bakıldığında öğrenci kazanımlarını ve programa alınacak konuların özellikleri şöyle tanımlamıştır.

İş Eğitimi derslerinde düzenlenen öğretme-öğrenme etkinlikleri sonucunda, öğrenciler;

a) Uygulanabilir bilgi ve beceriler geliştirir.

b) İş hayatında kullanılan araç-gereçleri tanır.

c) İş hayatında kullanılan kuram, ilke ve yöntemleri tanır .

d) Çeşitli meslek alanlarında üretilen ürünleri kalite, standart ve işlevleri açısından seçer.

e) Ürün satın alırken maliyet, garanti, değiştirme gibi unsurları dikkate alır.

f) Araçları emniyet, bakım ve çalışma kurallarına uyarak kullanır.

g) Çeşitli meslek alanlarmda üretilen ürünleri; ekonomik, sosyal ve işlevsel öğelerini dikkate alarak değerlendirir.

h) İş hayatındaki mesleklerden haberdar olur.

i) Kendi kendini tanir.

j) İlgi duyduğu meslek alanlarının ekonomik koşullarını bilir.

k) Mesleklerle ilgili ön yargilardan kurtulur. 
1) Mesleklere karşı sosyal değerler geliştirir.

m) Meslekler için gerekli olan temel becerilerden ve diğer özelliklerden haberdar olur.

n) Meslek alanını daha gerçekçi olarak seçebilir.

o) Karar verme becerisi gelişir.

p) e Çeşitli meslek alanlarında; teknolojik gelişmelerin etkilerini ve yönelmeleri bilir.

q) e Boş zamanlarını değerlendirmede kullanılabileceği araç-gereçleri tanır.

r) e Boş zamanlarını değerlendirebilecek beceriler kazanır.

s) Bilimsel ve. teknolojik gelişmeler ile sosyal refah arasındaki ilişkiyi bilir.

t) Sistemli düşünme ve planlı çalışma alışkanlığı kazanır.

u) Yaratıcılık gücü gelişir.

v) Bağımsız çalışma alışkanlığı gelişir.

w) Sorumluluk alma alışkanlığ 1 gelişir.

x) İşbirliği yapma ve yardımlaşma alışkanlığı gelişir.

y) Sağlıklı yaşamak, ailesinin ve toplumun sağlığını koruma alışkanlığı kazanır.

$\mathrm{Bu}$ derslerde programa. alınacak konuların belirlenmesinde;

a) Öğrencilerin gerçek hayatta bir ihtiyacını karşılayacak nitelikte olmasına,

b) Öğrencilerin ilgi v,e yeteneklerine uygun olmasına,

c) İş hayatını tanıtıcı nitelikte olmasına,

d) Karar verme-planlama-ürünü veya hizmeti meydana getirme kontrol ve değerlendirme aşamalarını kapsamasına,

e) Öğrencilerin diğer derslerde (Fen bilgisi, sosyal bilgiler, Türkçe, matematik gibi) öğrendikleri bilgileri uygulamaya aktarmalarına elverişli olmasına

dikkat edilmelidir.

Yukarıda belirlenen bilgi, beceri ve alışkanlıkların kazandırılmasında yöntem seçimi çok önemlidir. Bu nedenle yöntemlerin seçiminde ve kullanılmasında içeriğin özelliği ve öğrencinin ilgisi, psikolojik yapısı gibi özellikleri göz önünde tutulur. (Keser, 1987).

Günümüzde ise çok büyük bir yelpazede dijital cihaz kullanımı ve devasa boyutlarda veri ve bilgi kullanımı sebebiyle, bireylerinin önceki nesillerde ihtiyaç duyulmayan çeşitli beceriler ve stratejilere sahip olmaları gerekmektedir (Intel® Teach Program, 2014). Bu noktada teorik bilgilerin ürüne dönüştürülmesini ve 21.yy becerilerinin kazandırılmasında önemli bir rol üstlenen STEM okul öncesinden üniversiteye kadar Fen, Teknoloji, Mühendislik ve Matematik (Science, Technology, Engineering, Mathematics ) alanlarındaki bilgi ve becerilerin gelişmesini sağlayan bir eğitim yaklaşımıdır(Akgündüz, 2015). Bu yaklaşım, öğrencilerin bilimsel araştırma yöntemlerini kullanma, yaratıcılık, üretme, sorgulama becerilerinin gelişmesini ve öğrenme sürecindeki motivasyonlarının artmasını sağlamaktadır (Bakırcı \& Kutlu, 2018). A.B.D.'de özellikle üniversitede verilen nitelikli STEM eğitimini alan öğrenciler edindikleri ileri düzey STEM becerileriyle teknolojik buluşların ve üretimin desteklenmesine önemli katkı yapmışlardır(Çorlu, 2014). 
Dünya literatürü ve Türkiye' deki araştırmalar incelendiğinde STEM eğitim yaklaşımının tek türlü olmadığı görülmüştür. Bazı araştırmacılar bilim ağırlıklı, bazıları mühendislik ağırlıklı, bazıları teknoloji ağırlıklı ve bazıları da matematik ağırlıklı olarak eğitimleri planlamaktadırlar. Bu durumun değişkenliğinin nedeni ise, yaklaşımın;

a) -Bir veya birkaç ders saati süren etkinlikler hâlinde,

b) -Bir öğretim programı olarak,

c) -Bir ders ya da bir okul sistemi olarak,

d) -Okul içi ve/veya okul dışı etkinlikler olarak,

planlanabilme özgürlüğünün bulunmasıdır. Bu yaklaşımın Türkiye'deki en önemli planlamalarından biri 2005-2006 öğretim yılında değişen programlarda fen eğitiminin "Fen ve Teknoloji" dersi olarak programa yansitılmasıdır. Fen ile teknolojiyi entegre etmek amaciyla oluşturulmuş bu yapı, 2013 program değişikliğiyle yeniden fen bilimleri adını almış ve bir öğretim programı olarak STEM yaklaşımından faydalanılmıştır.

Günümüzde İlköğretim kademesinde okutulan Fen Bilimleri ders programları ile öğrencilerin 'fen okuryazarı' olması hedeflenmektedir (MEB, 2018). Bu kapsamda öğrencilerin;

a) fen bilimleri alt alanlarında (Fizik, Kimya, Biyoloji Astronomi, mühendislik, yer ve çevre bilimleri) ile ilgili temel bilgiler kazanmaları,

b) doğa-insan ilişkisini keşfetmeleri, doğayı anlamaları,

c) bilimsel süreç becerileri kazanmaları,

d) bilimin doğasını anlamaları,

e) günlük yaşamda fen bilimlerine ilişkin bilgi, konu ve alanlarda problem çözme becerileri geliştirmeleri,

f) Fen bilimleri alanlarında kariyer bilinci kazanmaları,

g) Fen bilimleri alanlarında girişimcilik becerileri geliştirmeleri,

h) Bilim insanı olmanın ve bilimsel bilgi oluşturmanın nasıl olduğunu anlamaları,

i) Doğal olaylara ilişkin ilgi duymaları, bunları merak etmeleri ve bunlara ilişkin olumlu tutum geliştirmeleri,

j) Bilimsel etik ilkeleri anlamaları ve uygulamaları amaçlanmaktadır (MEB 2018).

Etkili bir fen öğretimi ile fen okuryazarı olan bireyler, sosyal yaşam içinde temel yaşam becerilerini kazanmış, analitik düşünebilen, karar mekanizmasını etkili kullanan, yaratıcı, girişimci, iletişim kurabilen, takım çalışması yapabilen, yenilikçi, problem çözen, tasarımcı, disiplinlerarası ilişki kurabilen, eleştirel düşünebilen, sorgulayan, inovatif düşünen, buluş yapan (MEB, 2018); kavram yanılgılarına düşmeden bilimsel literatüre hakim (Yağbasan ve Gülçiçek, 2003); bilimsel bilginin değerine inanan ve bilimsel bilgiye nasıl ulaşacağını bilen, teknolojik gelişmeleri algılayıp yorumlayabilen (Hançer, Şensoy ve Yıldırım, 2003) özellikleri ile modern dünyaya yön vereceklerdir. Etkili fen öğretimi ile fen okuryazarı olarak yetişmiş bireylerin dünyanın temel sorunlarını çözebilen aktif bireyler olmaları amaçlanır. Bu bireylerin yetişmesi ise fen okuryazarı olmanın yanı sıra pek çok beceri setini kazanmış olmalarını gerektirir. Fen öğretiminde etkili öğrenmeyi hedefleyen bir yaklaşımda öğrenenlerde fene karşı olumlu tutum ve güçlü motivasyon geliştirmek üzere etkin yöntem ve tekniklerin işe koşulması son derece önemlidir. 
Fen bilimleri dersi ile STEM eğitiminin başarılı entegrasyonu için öğretmenlerin bu süreçte STEM bakış açılarını geliştirmeleri ve "bilgiyi bilgi için" öğretmek yerine "bilgiyi kullanmak için öğretmek" yaklaşımına sahip olmaları gerekmektedir. Bu yaklaşım ile öğretmenler, öğrencilerin 21. yüzyıl becerileri ile paralel olan becerilerinin gelişimini sağlayacak ve öğrencilerin yaratıcılık, sorumluluk duygusu gibi becerilerini ortaya çıkararak öğrencilerin yüzyılın gereklerine göre aktif bir eğitim sürecine erişmelerini sağlayacaklardır. Bu sürecin öğrencilerin STEM alanlarında meraklı, yetenekli, araştıran sorgulayan özellikte olmasını ve teorik bilgileri öğrenmede daha istekli olmalarını sağlayacağı düşünülmektedir. (Tüysüz vd. 2018).

K-12 fen eğitimi programının vurgulanan yenilikleri gerçekleştirebilmesi için, öğretmenlerin eğitiminde bütünleşik öğretmenlik bilgisine sahip olması ve öğrenme süreçlerinin "farklı disiplinlerin anlamlı, kaliteli, üst düzey, yaratıcı ve eleştirel düşünmeyi kapsayacak şekilde yapılandırılması (STEM) gerekmektedir. Mühendislik tasarımı ve bilimsel araştırmasorgulamanın sınıf içi uygulamalarında bazı farklılıklar bulunmaktadır. (Eroğlu \& Bektaş, 2016; Altan, Yamak \& Kırıkkaya, 2016; Yıldırım \& Altun, 2015; Şahin \& Ayar, 2014) Bu farklılıkların içinde yanlış uygulamaların da bulunduğu ve yanlışlıkların ortadan kaldırılmasının gerekliliği düşünüldügüünde; STEM eğitiminin yürütülmesinde, etkinliklerin Fen Bilimleri, Matematik vb. ders kazanımlariyla entegre olması ve bu dersleri veren alan uzmanlarının STEM eğitimi konusunda mesleki niteliklerinin iyi olması büyük önem arz etmektedir. Bu nedenle ülkemizde STEM eğitim uygulamalarının içeriği, öğretmenin niteliği ile ilgili araştırmaların yaygınlaştırılması ve öğrencinin öğrenme ihtiyaçları ve motivasyonlarını geliştirmeye yönelik çalışmalarının yapılması gerekir.

Bu araştırmanın amacı, ortaokul 5., 6., 7. ve 8. sınıfa devam eden öğrencilere uygulanan STEM eğitim etkinliklerinin, öğrencilerin STEM alanlarına yönelik tutumlarını ve fen öğrenmeye yönelik motivasyonlarına etkisini incelemektir. Araştırmada aşağıdaki sorulara cevap aranmıştır.

- STEM eğitim etkinlikleri uygulanan Ortaokul öğrencilerinin STEM alanlarına yönelik tutum ön - son test puanları arasında manidar farklılık var midır?

- STEM eğitim etkinlikleri uygulanan Ortaokul öğrencilerinin fen öğrenmeye yönelik motivasyon ön - son test puanları arasında manidar farklılık var mıdır?

\section{Yöntem}

\section{Araştırma Modeli}

$\mathrm{Bu}$ araştırma, STEM Eğitiminin fen öğrenmeye yönelik motivasyonun STEM eğitimi öncesi ve sonrasındaki düzeyleri ve aralarındaki ilişki inceleneceğinden deneme öncesi deneysel desenlerden tek grup ön test-son test modeli ile yapılandırılmıştır. Deneysel desen; bağımsız bir değişkeninin, bağımlı bir sonuç değişkeni üzerinde bir etkisi olup olmadığına karar vermek için kullanılabilir (Creswell, 2017). Bu araştırma desenlerinde mutlaka karşılaştırma vardır. Tek grup ön test-son test modeli ise, gelişigüzel bir gruptan hem işlem öncesinde, hem de sonrasında ölçüm alınarak bağımsız değişken uygulanmasına dayanır (Karasar, 2013). Bu kapsamda bu çalışmada, ortaokul öğrencilerinin STEM Eğitimi almaları öncesi ve sonrasında STEM alanlarına yönelik tutumları ile fen Öğrenmeye yönelik motivasyonlarındaki olası incelenmiştir. Bu yönleriyle araştırma deneme öncesi deneysel desenlerden tek grup ön-son 
test desenine uygundur. Araştırmacının uygulamayı yaptığı okulda STEM eğitimi ilk olarak 2018 - 2019 eğitim öğretim yılından itibaren tüm seviyelerde ve öğrencilere uygulanmaya başlanmıştır. Araştırmada kurum tarafından yürütülen bir sürecin incelenmesi yapıldığından çalışmada kontrol grubu kullanılmamıştır.

\section{Evren ve Örneklem / Çalışma Grubu / Katılımcılar}

STEM Eğitimi'nin gerektirdiği fiziksel alt yapı, materyal imkanı, öğretmen imkanı ve öğrenciye ulaşılabilirlik gibi faktörlere bağlı olarak araştırmanın evreni, STEM Eğitimi veren okullarla sınırlıdır. Bu kapsamda araştırma, gönüllülük esasına dayalı olarak Ankara ili Etimesgut ilçesinde bulunan bir okuldaki 70 ortaokul öğrencisinin tümüyle yürütülmüştür. Çalışmalar müfredat eğitimi değil beceri gelişimini destekleyen etkinlikler şeklinde yürütüldüğünden tüm seviyelerde aynı etkinlikler kullanılmıştır. Bu öğrencilerin sınıf seviyesi ve cinsiyet dağılımı Tablo 1'de verilmiştir.

Tablo 1: Örneklemde Yer Alan Öğrencilerin Sınıf Seviyelerine ve Cinsiyetlerine Göre Dağılımı

\begin{tabular}{cccccc}
\hline Sinıf Seviyesi & Erkek $(\mathrm{F})$ & $\%$ & Kadın $(\mathrm{F})$ & $\%$ & Toplam \\
\hline 5 & 1 & 1 & 12 & 18 & 13 \\
\hline 6 & 3 & 4 & 7 & 10 & 10 \\
\hline 7 & 9 & 13 & 2 & 3 & 11 \\
\hline 8 & 23 & 32 & 13 & 19 & 36 \\
\hline Toplam & 36 & 50 & 34 & 50 & 70 \\
\hline
\end{tabular}

Tablo 1 'de görüldüğü gibi cinsiyet için ifade edilen frekans ve yüzdelerin birbirine yakın olduğu ve ayrıca en çok katılanın 8. sınıf öğrencileri, en az katılanın ise 6. sınıf öğrencileri olduğu görülmektedir.

\section{Veri Toplama Araçları}

Bu çalışmada; "STEM Eğitimine Yönelik Tutum Ölçeği" ve "Fen Öğrenmeye Yönelik Motivasyon Ölçeği" kullanılmıştır.

Karg1'nın (2019) geliştirdiği STEM Eğitimine yönelik tutum ölçeği, 33 maddeden oluşan beşli likert tipinde bir ölçektir. Beş alt boyuttan oluşan bu ölçek ortaokulda öğrenim gören 200 kişiye uygulanmıştır. Yapı geçerliğini belirlemek için yapılan faktör analizi sonucunda KMO değeri 0,854, Bartlett testi değeri ise $\chi 2=3613,635 ; p<, 05$ elde edilmiştir. Bu ise, verilerin faktör analizine uygun olduğunu ifade etmektedir. Ayrıca nihai ölçeğin Cronbach'ın Alpha güvenirlik katsayısı .912 elde edilmiştir. Faktör yuik değerleri 0,446 ile 0,824 arasında değişmektedir. 1 . boyutun açıkladığ varyans $10,787,3$. boyutun açıkladığı toplam varyans $8,111,4$. boyutun açkladığ1 toplam varyans $6,597,5$. boyutun açıkladığ 1 toplam varyans 5,443'tür. STEM Tutum ölçeğinde 5 boyut toplam varyansın 58,983'nü açıklamaktadır.

Dede ve Yaman'ın (2008) geliştirdiği Fen Öğrenmeye Yönelik Motivasyon Ölçeği ise, 23 madde ve beş alt boyuttan oluşan beşli likert tipinde bir ölçektir. Bu ölçek ortaokulda öğrenim gören 421 kişiye uygulanmıştır. Yap1 geçerliğini belirlemek için yapılan faktör analizi sonucunda KMO değeri 0,850, Bartlett testi değeri ise $\chi 2=1840,91 ; p<, 01$ elde edilmiştir. Bu ise, verilerin faktör analizine uygun olduğunu ifade etmektedir. Ayrıca nihai ölçeğin 
Cronbach'ın Alpha güvenirlik katsayısı 80 elde edilmiştir. Faktör yuik değerleri 0,475 ile 0,736 arasında değişmektedir. 1 . boyutun açıladığ1 toplam varyans $21,37,2$. boyutun açıkladığ toplam varyans $7,88,3$. boyutun açıkladığ 1 toplam varyans $7,27,4$. boyutun açıkladığ toplam varyans $5,88,5$. boyutun açıkladığı toplam varyans 4,76 'tür. Motivasyon ölçeğinde 5 boyut toplam varyansın 47,16 'sını açıklamaktadır.

\section{Verilerin Toplanması ve Analizi}

Araştırmada 5, 6, 7 ve 8.sınıfta eğitim gören toplam 70 ortaokul öğrencisinden veri toplanmış ve analizler bu öğrencilerden elde edilen verilere göre yapılmıştır. Analizler, SPSS 22.0 yazılımıyla gerçekleştirilmiştir. Analizlerde kullanılan istatistiksel testlerin anlamlı olup olmadığını belirlemek için anlamlılık düzeyi olarak 0.05 değeri kullanılmıştır.

Ortaokul öğrencilerinin fen öğrenmeye yönelik motivasyonlarının ne düzeyde olduğunu belirlemek için, Fen Öğrenmeye Yönelik Motivasyon Ölçeğinden almış oldukları puanlara ait betimsel istatistiksel hesaplanmıştır. Bu işlem hem ön-test hem de son-test puanları için yapılmıştır.

STEM eğitimi uygulanan ortaokul öğrencilerinin fen öğrenmeye yönelik motivasyonlarının ön test puanlarıyla ve son test puanları arasında anlamlı farklılık olup olmadığını belirlemek için ilişkili örneklemler için t-testi ve Wilcoxon işaretli sıralar testi kullanılmıştır. Son-test ve öntest puanları arasındaki fark puanlarının normal dağılımdan aşırı sapma göstermediği durumlarda ilişkili örneklemler için t-testi, normallik varsayımının sağlanmadığ durumlarda ise Wilcoxon işaretli sıralar testi kullanılmıştır. Normallik varsayımının test edilmesi sırasında, çarpıklık değerinin kendi standart hatasına bölünmesi sonucu elde edilen değerler incelenmiştir. Bu değerler 0.05 hata düzeyinde kritik z değeri olan 1.96 ile karşılaştırılmıştır. Çarpıklık/standart hatanın mutlak değeri 1.96'dan küçük olduğunda normallik varsayımının sağlandığı sonucuna varılmıştır.

\section{Bulgular}

\section{STEM Ĕ̆itim Etkinliklerinin STEM Bilim Alanına Yönelik Tutum Üzerindeki Etkisine Yönelik Bulgular}

STEM eğitiminin öğrencilerin STEM alanlarına yönelik tutumu üzerindeki etkisini belirlemek için STEM Alanlarına Yönelik Tutum Ölçeği, STEM eğitimden önce ve sonra uygulanmıştır. Son-test ve ön-test puanları arasındaki fark puanlarının normal dağılımdan aşırı sapma göstermediği durumlarda ilişkili örneklemler için t-testi, normallik varsayımının sağlanmadığı durumlarda ise Wilcoxon işaretli sıralar testi kullanılmıştır. (Normallik varsayımı için çarpıklık değerinin kendi standart hatasına bölünmesi sonucu elde edilen değerler incelenmiştir. Bu değerler 0.05 hata düzeyinde kritik $\mathrm{z}$ değeri olan 1.96 ile karşılaştııılmıştır. Çarpıklık/standart hatanın mutlak değeri 1.96'dan küçük olduğunda normallik varsayımının sağlandığı sonucuna varılmıştır.)

Matematiğe karşı tutum, teknolojiye karşı tutum ve STEM uygulamalarına karşı tutum alt boyutları ile ölçek toplamının ön - son test uygulamaları arasındaki fark puanları normallik varsayımını sağlandığı için ön - son test puanlarının karşılaştırılmasında ilişkili örneklemler için t-testinden faydalanılmıştır. T-testi analiz sonuçları Tablo 2'de gösterilmiştir. 
Tablo 2: Normallik Varsayımını Sağlayan STEM Tutum Ölçeği Boyutları Ön - Son Test Puanlarının Karşılaştırılmasına İlişkin Sonuçlar

\begin{tabular}{|c|c|c|c|c|c|c|c|c|}
\hline Boyut & Ölçüm & $\mathrm{N}$ & $\overline{\mathbf{x}}$ & SS & $\mathrm{sd}$ & $\mathrm{t}$ & $\mathrm{p}$ & $\begin{array}{c}\text { Etki } \\
\text { Büyüklüğü* }\end{array}$ \\
\hline \multirow[t]{2}{*}{ Matematik } & Ön-test & 70 & 22.74 & 4.96 & 69 & 3.04 & 0.00 & 0.36 \\
\hline & Son-test & 70 & 20.01 & 6.02 & & & & \\
\hline \multirow[t]{2}{*}{ Teknoloji } & Ön-test & 70 & 19.46 & 5.08 & 69 & 0.00 & 1.00 & - \\
\hline & Son-test & 70 & 19.46 & 5.46 & & & & \\
\hline \multirow[t]{2}{*}{ STEM Uygulamaları } & Ön-test & 70 & 45.16 & 10.40 & 69 & -1.77 & 0.08 & - \\
\hline & Son-test & 70 & 48.30 & 12.03 & & & & \\
\hline \multirow[t]{2}{*}{ Toplam } & Ön-test & 70 & $\begin{array}{c}123.6 \\
0\end{array}$ & 22.25 & 69 & 0.02 & 0.99 & - \\
\hline & Son-test & 70 & $\begin{array}{l}123.5 \\
4\end{array}$ & 27.02 & & & & \\
\hline
\end{tabular}

SS:Standart sapma, sd:serbestlik derecesi

${ }^{*}$ Cohen'in d katsayıs

Tablo 2' de görüldüğgü üzere, matematiğe karşı tutum ön - son test puan ortalamaları arasında anlamlı fark bulunmaktadır $(\mathrm{t}(69)=3.04, \mathrm{p}<0.05)$. Matematiğe karşı tutum son-test puan ortalaması ( $\overline{\mathbf{X}}=20.01)$, ön-test puan ortalamasından $(\overline{\mathbf{X}}=22.74)$ anlamlı olarak düşüktür. Etki büyüklüğü küçük düzeydedir $(\mathrm{d}=0.36)$. Cohen'in $\mathrm{d}$ katsayısının mutlak değerinin 2 ile 5 arasında olması küçük etki büyüklügünün göstergesidir (Field, 2013). Teknolojiye karşı tutum STEM eğitimi sonrasında anlamlı olarak değişmemiştir $(t(69)=0.00, p>0.05)$. STEM uygulamalarına karşı tutum ön-test ve son-test puan ortalamaları arasında anlamlı fark olmadığı görülmektedir $(\mathrm{t}(69)=-1.77, \mathrm{p}>0.05)$. Öğrencilerin STEM Tutum Ölçeğinden STEM eğitimi öncesinde $(\overline{\mathbf{X}}=123.60) \quad$ ve sonrasında $(\overline{\mathbf{X}}=123.54)$ aldıkları toplam puanların ortalamaları arasında anlamlı fark yoktur. Bu bulgulara göre, öğrencilere uygulanan STEM eğitiminin STEM alanlarına yönelik tutum üzerinde genel olarak etkili olmadığı çıkarımı yapılabilir.

Fene ve mühendisliğe karşı tutum alt boyutlarından elde edilen puanlar normallik varsayımını sağlayamadığından bu alt boyutların ön-test ve son-test puanlarını karşılaştırmada Wilcoxon işaretli sıralar testi kullanılmıştır. Wilcoxon işaretli sıralar testi analizi sonuçları Tablo 3'de gösterilmiştir.

Tablo 3: Normallik Varsayımını Sağlamayan STEM Tutum Ölçeği Boyutları Ön-Son Test Puanlarının Karşılaştırılmasına İlişkin Sonuçlar

\begin{tabular}{lllllcl}
\hline Boyut & Son test-Ön test & $\mathrm{N}$ & Sıra Toplamı & Sıra Ortalaması & $\mathrm{z}$ & $\mathrm{p}$ \\
& Negatif Sıra & 27 & 904.50 & 33.50 & $-1.47^{*}$ & 0.14 \\
\hline Fen & Pozitif Sıra & 40 & 1373.50 & 34.34 & & \\
& Eşit & 3 & & & & \\
\hline
\end{tabular}




\begin{tabular}{lllllll}
\hline & Negatif Sıra & 39 & 1439.50 & 36.91 & $-1.39^{* *}$ & 0.17 \\
\hline Mühendislik & Pozitif Sıra & 30 & 975.50 & 32.52 & & \\
& Eşit & 1 & & & & \\
\hline
\end{tabular}

${ }^{*}$ Negatif sıralara dayalı olarak hesaplanmıştır.

**Pozitif sıralara dayalı olarak hesaplanmıştır.

Tablo 3' da görüldüğü üzere, fene karşı tutum ön-son test puanları arasında fark puanlarının sira ortalamasinın son test lehine olmasina ragmen anlamlı fark bulunmamaktadir $(\mathrm{z}=-1.47$, $\mathrm{p}>0.05$ ). Öğrencilerin mühendisliğe karşı tutumu, STEM eğitimi sonrasında anlamlı olarak değişmemiştir $(\mathrm{z}=-1.39, \mathrm{p}>0.05)$. Fark puanlarının sıra ortalamasının ön-test lehine olduğu görülmektedir. Bu durum, bazı öğrencilerin son-test puanlarının genel olarak ön-test puanlarına göre önemli derecede düşük olmasıyla ilişkili olabilir. Mühendisliğe karşı tutum son-test puan ortalamasının ön-test puan ortalamasından düşük olması da, bu çıkarımı desteklemektedir. Bazı öğrencilerin mühendisliğe karşı tutum puanlarındaki düşüşe rağmen aradaki farkın anlamlı olmadığı görülmektedir.

STEM Eğitim Etkinliklerinin Fen Öğrenmeye Yönelik Motivasyon Üzerindeki Etkisine Yönelik Bulgular

STEM eğitiminin öğrencilerin fen öğrenmeye yönelik motivasyonu üzerindeki etkisini belirlemek için Fen Öğrenmeye Yönelik Motivasyon Ölçeği, STEM eğitimden önce ve sonra uygulanmıştır. Ölçeğin alt boyutlarından ve toplamınından alınan ön-test ve son-test puanlarını karşılaştırmak için ilişkili örneklemler için t-testi ve Wilcoxon işaretli sıralar testi kullanılmıştır. Son-test ve ön-test puanları arasındaki fark puanlarının normal dağılımdan aşırı sapma göstermediği durumlarda ilişkili örneklemler için t-testi, normallik varsayımının sağlanmadığ 1 durumlarda ise Wilcoxon işaretli sıralar testi kullanılmıştır.

Ön-test son-test uygulamaları arasındaki fark puanları normallik varsayımını sağladığı için araştırma yapmaya ve işbirlikli çalışmaya yönelik motivasyon alt boyutlarının analizinde $\mathrm{t}$ testi kullanılmıştır. T-testi analiz sonuçları Tablo 4' de gösterilmiştir.

Tablo 4: Normallik Varsayımını Sağlayan Fen Öğrenmeye Yönelik Motivasyon Ölçeği Boyutları Ön-Son Test Puanlarının Karşılaştırılmasına İlişkin Sonuçlar

\begin{tabular}{|c|c|c|c|c|c|c|c|c|c|c|}
\hline Boyut & & & Ölçüm & $\mathrm{N}$ & $\overline{\mathrm{X}}$ & SS & sd & $\mathrm{t}$ & $\mathrm{p}$ & $\begin{array}{l}\text { Etki } \\
\text { büyüklüğ̈ü* }\end{array}$ \\
\hline \multirow{2}{*}{$\begin{array}{l}\text { Araştırma } \\
\text { Motivasyon }\end{array}$} & Yapmaya & Yönelik & Ön-test & 70 & 22,30 & 5,08 & 69 & -3.82 & 0,00 & $-0,46$ \\
\hline & & & Son-test & 70 & 25,23 & 3,87 & & & & \\
\hline \multirow{2}{*}{\multicolumn{3}{|c|}{ İşbirlikli Çalışmaya Yönelik Motivasyon }} & Ön-test & 70 & 13,13 & 2,47 & 69 & 0,93 & 0,35 & - \\
\hline & & & Son-test & 70 & 12,74 & 2,23 & & & & \\
\hline
\end{tabular}

SS:Standart sapma, sd:serbestlik derecesi

${ }^{*}$ Cohen'in d katsayıs

Tablo 4'de görüldüğü üzere, araştırma yapmaya yönelik motivasyon ön-son test puanları arasında anlamlı fark bulunmaktadır $(\mathrm{t}(69)=-3.82, \mathrm{p}<0.05)$. Araştırma yapmaya yönelik motivasyon son-test puan ortalamasi $(\overline{\mathrm{X}}=25.23)$, ön-test puan ortalamasindan $(\overline{\mathrm{X}}=22.30)$ 
anlamlı olarak yüksektir. Bu sonuca göre, Öğrencilere uygulanan STEM eğitimi öğrencilerin araştırma yapmaya yönelik motivasyonunu olumlu etkilemiştir. STEM eğitiminin araştırma yapmaya yönelik motivasyonu üzerindeki etkisi küçük büyüklüktedir (d=-0.46). İşbirlikli çalışmaya yönelik motivasyon, STEM eğitimi sonrasında anlamlı olarak değişmemektedir $(\mathrm{t}(69)=0.93, \mathrm{p}>0.05)$. Bu sonuc, STEM eğitiminin işbirlikli çalışmaya yönelik motivasyonu üzerinde bir etkiye sahip olmadığını göstermektedir.

Performansa, iletişime ve katılıma yönelik motivasyon boyutları ile ölçeğin tamamı için öntest ve son-test arasındaki fark puanları normallik varsayımını sağlanamadığından bu alt boyutların ön-test ve son-test puanlarını karşılaştırmada Wilcoxon işaretli sıralar testi kullanılmıştır. Wilcoxon işaretli sıralar testi sonuçları Tablo 5'de gösterilmiştir.

Tablo 5: Normallik Varsayımını Sağlamayan Fen Öğrenmeye Yönelik Motivasyon Ölçeği Boyutları Ön - Son Test Puanlarının Karşılaştırılmasına İlişkin Sonuçlar

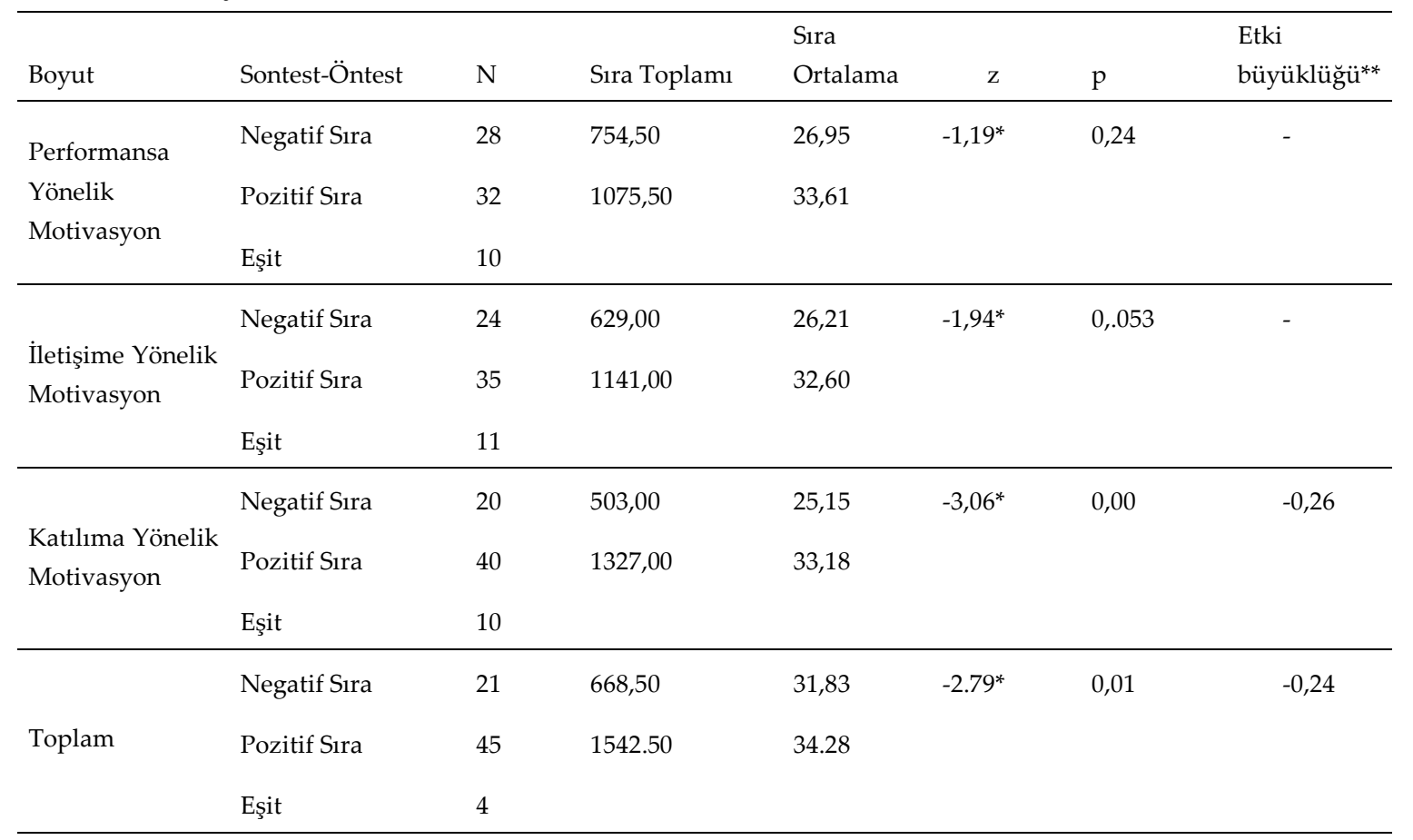

*Negatif sıralara dayalı olarak hesaplanmıştır.

**Wilcoxon işaretli sıralar testi için r etki büyüklüğü (Field, 2013)

Tablo 5'de görüldügü üzere, performansa yönelik motivasyon ön ve son-test puanları arasında anlamlı fark bulunmamaktadır $(z=-1.19, p>0.05)$. Son-test puanlarının daha yüksek olduğu pozitif sıradaki fark puanlarının sıra ortalaması daha yüksek olmasına rağmen anlamlı fark olmadığ da anlamlı fark bulunmamaktadır $(\mathrm{z}=-1.94, \mathrm{p}>0.05)$. Katılıma yönelik motivasyon ön ve sontest puanları arasında anlamlı fark vardır $(\mathrm{z}=-3.06, \mathrm{p}<0.05)$. Son-test puanlarının daha yüksek olduğu pozitif sıradaki fark puanlarının sıra ortalaması anlamlı olarak daha yüksektir. Bu bulguya göre, öğrencilere uygulanan STEM eğitimi öğrencilerin katılıma yönelik motivasyonu üzerinde olumlu bir etkiye sahiptir. Fen Öğrenmeye Yönelik Motivasyon Ölçeğinin tamamından elde edilen ön ve son-test puanları arasında anlamlı fark olduğu görülmektedir $(\mathrm{z}=-2.79, \mathrm{p}<0.05)$. Son-test puanlarının daha yüksek olduğu pozitif sıradaki fark puanlarının sıra ortalaması anlamlı olarak daha yüksektir. Bu bulgu, STEM eğitimi sonrasında öğrencilerin 
fen öğrenmeye yönelik motivasyonlarını olumlu olarak arttığını göstermektedir. Ancak etki küçük düzeydedir $(r=-0.24)$.

\section{Tartışma, Sonuç ve Öneriler}

\section{Öğrencilerin STEM Alanlarına Yönelik Tutumları}

Tutum, "bir bireye atfedilen ve onun bir psikolojik obje ile ilgili düşünce, duygu ve davranışlarını düzenli bir biçimde oluşturan bir eğilimdir" (Kağıtçıbaşı, 1985). Tutum kavramı incelendiğinde, tutumun bir olay ya da nesneyle ilgili yaşantı ve deneyimleri sonucunda kişinin davranışlarını yönlendiren dinamik bir etkiye sahip duygusal ve zihinsel hazırlık durumu olarak tanımlandığı da görülmektedir (Tavşancıl, 2014). Bireyin tutumlarında düşünce, duygu ve davranışlarının uyumu söz konusudur. Birbirleriyle büyük oranda uyum halinde bulunan bu üç faktör tutumların öğeleri olup 'ABC modeli' olarak da adlandırılır. Yerleşmiş (güçlü) tutumlarda bilişsel, duygusal ve davranışsal öğelere tam olarak rastlanırken daha zayıf tutumlarda ise özellikle davranışsal öğe çok zayıf kalabilir. Bireyin amacına, amacına ulaşmak için bulunduğu eylemlere ve nihai olarak ulaştığı sonuca ve yanı sıra kendi kişilik özelliklerine karşı olumlu tutum sergilemesi beklenir. Bireyin bir durum karşısında sergilediği olumsuz tutum, bireyin söz konusu durumu reddetmesine bağlı olarak bu durumu analiz etmesinde, durum karşısında bilgi ve becerilerini kullanmasında, durumla ilgili hazırbulunuşluk ve güdülenmede ciddi bir engel teşkil eder (Kağıtçıaşı, 1985; Başaran, 1990; Feldman 1993, Morgan, 1995).

Tutum; devamlılı̆̆ı olan, dinamik, kişinin yaşantı ve deneyimleri etkileyen ve birçok faktörden etkilenen bir eğilimdir. Eğitim alanındaki tutumları etkileyen faktörler olarak öğretmenler, eğitim ortamları, uygulanan programlar gibi birçok bileşen sayılabilir. Açıkgöz (1992), öğrencilerin konu, öğretmen, okul ortamı gibi bileşenlere ilişkin tutumunun eğitimle ilgili olumlu tutumlara sahip olmaları sonucunu doğuracağını, ayrıca kişinin yaşantılarından ve başka kişilerle olan etkileşiminden tutumlarının önemli ölçüde etkilendiğini, Erden (1998) ise öğretmenin kişisel ve mesleki niteliklerinin öğrenci başarısı ve eğitim sürecinin kalitesini etkileyen çok önemli bir faktör olduğunu ayrıca öğretmenin kişisel ve mesleki niteliklerinin öğrencinin derse yönelik olumlu tutumlar geliştirmede çok önemli bir etkiye sahip olduğunu belirtmiştir.

Bu kapsamda ilgili ilgili araştırmalar incelendiğinde, (Stohlmann ve arkadaşları 2012; Wu ve arkadaşları 2018; Yıldırım ve arkadaşları 2017; Kelly ve arkadaşları 2019) STEM eğitimine yönelik tutumları etkileyen en önemli bileşenlerden ikisinin, uygulanan eğitimin programı ve öğretmenlerin STEM alanlarına ilişkin tutum ve yeterlilikleri olduğu sonucuna ulaşılmıştır.

Ilgili araştırmaları detaylandırmak gerekirse;

Stohlmann ve arkadaşlarının (2012), yürüttüğü çalışmalarda STEM eğitimi sürecinde, kaliteli bilim-teknoloji-mühendislik-matematik eğitimlerinin öğrencilerin başarısı için çok gerekli olduğu müfredat programlarına entegre STEM eğitiminin öğrencilerin öğrenme süreçlerini daha anlamlı ve kalıcı hale getirdiğini sonucuna ulaştırmıştır. Ayrıca STEM eğitimi uygulayan öğretmenlerin daha fazla araştırma, tartışma, bilgi ve deneyim sahibi olmaları gerektiği ve bunun için öğretmenlerin sürekli olarak hizmet içi eğitimlerle desteklenmesi gerektiğinin vurgulandığı görülmektedir. 
Wu ve arkadaşlarının (2018), farklı versiyonlarda STEM kurslarıyla verdikleri eğitimlerde öğrencilerin matematik alanlarına ilişkin tutumlarında anlamlı ve kuvvetli bir düşüş olduğunu tespit etmişlerdir. Aynı araştırma, klasik matematik süreçlerinin öğrencilerin matematik alanına karşı tutumunu daha az düşürdügünü ortaya koymuştur.

Yıldırım ve arkadaşları (2017), yaptığı araştırmada ise STEM uygulamaları ile tam öğrenmenin birlikte uygulandığı eğitim süreçlerinin, sadece etkinlik temelli STEM uygulamalarının yürütüldüğü ya da hiç uygulanmayan süreçlere göre akademik başarı ve tutum üzerinde daha etkili olduğunu sonucuna ulaşmışlardır.

Kelly ve arkadaşlarının (2019) yaptığı araştırmada ise öğretmenlerin STEM eğitimi ve entegrasyonuna yönelik algılarını içeren 25 makale üzerinde yaptığı incelemenin sonucunda öğretmenlerin bilgiyi kolaylaştırıcı rolünü nasıl oynayacaklarını ve öğrenciyi risk almaya nasıl teşvik edeceklerini öğrenmek zorunda olduklarına vurgu yapılmıştır. Bunun için öğretim reformunun yanında öğretmenler için yüksek kaliteli eğitim alabilecekleri profesyonel gelişim mekanizması kurulması gerektiğine dikkat çekilmektedir. Ayrıca, araştırmada öğretmenlerin STEM eğitimiyle ilgili sahip oldukları içerik bilgisi, duyuşsal ihtiyaçları hizmet içi eğitimlerle eğitim öğretim süreci boyunca devamlı olarak desteklenmesi gerektiği vurgulanmaktadır. Araştırmanın sonuçlarında, öğretmenlerin tek disiplinden çoklu disipline geçebilmeleri için zaman ihtiyaçları olduğunu ve bu nedenle ders planlamalarını ilgili disiplinlerdeki meslektaşlarıyla birlikte yapmaları gerektiği vurgulanmıştır.

Yukarıda belirtilen araştırma sonuçlarının, araştırmada elde edilen bulguları ve sonuçları desteklediği görülmektedir.

$\mathrm{Bu}$ kapsamda, yapılan araştırma sonucunda, öğrencilere uygulanan STEM eğitiminin öğrencilerin STEM alanlarına yönelik tutumuna etkisi incelendiğinde, öğrencilerin STEM alanlarına yönelik tutumları üzerinde genel olarak olumlu etkisi olmadığı sonucunu vermiştir. Analizler; matematiğe karşı tutum son-test puan ortalamasının ön-test puan ortalamasından anlamlı olarak düşük olduğunu gösterirken, teknoloji, mühendislik, fen ve STEM uygulamaları boyutlarındaki ön-test ve son-test puanları arasında anlamlı bir fark olmadığını göstermektedir (Tablo 2-3).

Elde edilen bulgular STEM eğitimine yönelik öğrenci tutumlarının STEM eğitiminin kalitesinden STEM eğitim programını uygulayan eğitimcilerin fen, matematik, teknoloji ve mühendislik alanlarındaki bilgi, deneyim, araştırma ve tartışma süreçlerindeki mesleki yeterlilikleriyle doğrudan ilişkili olduğunu göstermektedir. Özellikle Yıldırım ve arkadaşları (2017), Wu ve arkadaşları (2018), Margot ve Kettle (2019)'in yaptığı araştırma sonuçlarında öğretmen tutumu, mesleki becerileri ve kullanılan eğitim modelinin öğrencilerin STEM eğitim süreçlerindeki beceri gelişimlerini, akademik başarılarını, STEM alanlarına yönelik farkındalıklarını, akademik başarı ve tutumlarını etkilediği görülmüştür. Bu ise yürütülen araştırmanın sonuçlarıyla örtüşmektedir. Ayrıca araştırmada STEM eğitimini uygulayan öğretmenin branşının bilişim teknolojileri uzmanlık alanı olması nedeniyle teknoloji ağırlıklı bir eğitim süreci yürüttüğü görülmüş, bu durum etkinliklerin diğer STEM alanlarına yönelik boyutlarda zayıf kalmasına sebep olmuştur. Öğretmenin yıl boyunca yürüttüğü etkinliklere ait yıllık plan ve ders senaryoları incelendiğinde bu sonucu desteler kanıtlar görülmüştür.

Ayrıca, STEM eğitimi uygulanan okulun derslerinin planlaması ve uygulanması yapılandırmacı yaklaşımın öğretim modelleri ile yapılmaktadır. Bu durum öğrencilerin öntest sonuçlarında STEM alanlarına yönelik ön-test tutum puanlarının yüksek olmasına neden 
gösterilebilir. Çünkü Yapılandırmacı ve proje tabanlı öğrenme yaklaşımı da beceri gelişimini ve disiplinler arası öğrenmeyi destekler niteliktedir. Betimsel istatistiklerde elde edilen bulgulardan bu sonucun elde edilmesinde, öğrencilerin müfredat dahilinde yapılandırmacılık temelli aldıkları Fen Bilimleri dersinin etkili olabileceği düşünülmektedir.

\section{Öğrencilerin Fen Öğrenmeye Yönelik Motivasyonlarına İlişkin Sonuçlar}

Motivasyon kavramını tanımlamadan önce güdü kavramını açklamak gerekir. Bunun nedeni ise güdü kavramının, motivasyon kavramının özü olmasıdır. Güdü "bireyi bir harekette bulunmaya ya da bir hareket yolunu diğerine tercih etmeye itecek şekilde etkileyen sürücü kuvvet ve faktöre" denir(Dandrade, 1992).

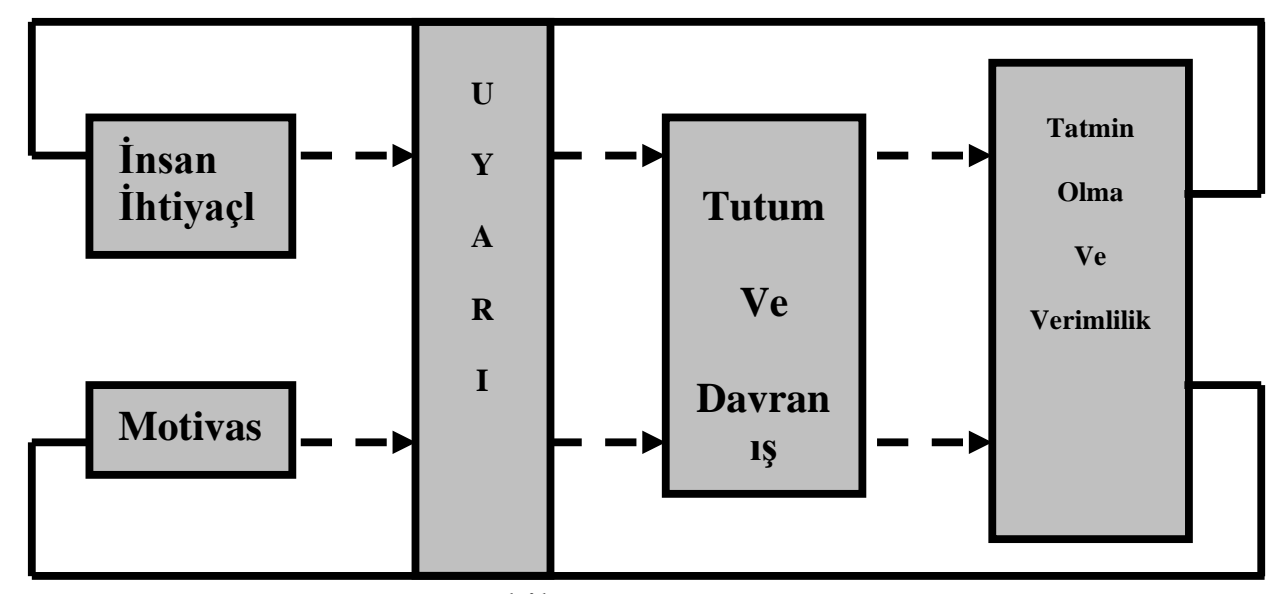

Şekil 1. Motivasyon Süreci

Şekil 1'de görüldüğü gibi, bir güdü etkisiyle belirli bir eylemde bulunma süreci motivasyon olarak ifade edilebilir. Bir birey herhangi bir şeye karşı belirli bir ihtiyaç duyduğunda bu ihtiyacı gidermek için bir takım davranışlarda bulunur. Bu davranışları da içine alan motivasyon süreci dört temel aşamadan oluşur. Bunlar; ihtiyaç, uyarılma, davranış ve doyum olarak ifade edilmektedir.

Akbaba'ya (2006) göre, motivasyon öğrencilerin davranışlarının şiddeti, yönü, kararlılığı ve eğitim ortamlarında istenilen amaca ulaşmadaki hızını belirleyen en önemli güç kaynaklarından biridir. Bu nedenle öğrencinin başarıya ulaşabilmesi için amaçlanan yönde motive edilmesi gerekmektedir. Çünkü motive edilen birey işini zevkle yapar, böylece her alanda kişisel verimliliği de artar.

Öğrencilere uygulanan STEM eğitim etkinliklerinin öğrencilerin Fen öğrenmeye yönelik motivasyon üzerindeki etkisi incelendiğinde, öğrencilere uygulanan STEM eğitimi öğrencilerin araştırma yapmaya ve katılıma yönelik motivasyonu üzerinde olumlu bir etkiye sahip olduğu. İş birlikli çalışmaya, performansa ve iletişime yönelik motivasyon üzerinde ise bir etkiye sahip olmadığı sonucuna ulaşılmıştır. Fen öğrenmeye yönelik motivasyon ölçeğinin tamamından elde edilen ön-test son-test puanları incelendiğinde ise öğrencilerin fen öğrenmeye yönelik tutumlarının olumlu olarak arttığ 1 belirlenmiştir. Ancak bu etki küçük düzeyde gerçekleşmiştir. (Tablo 4-5).

$\mathrm{Bu}$ konuyla ilgili araştırmalar incelendiğinde;

Çevik ve arkadaşları (2018), STEM etkinliklerinin öğrencilerin STEM başarısı, fene yönelik motivasyonları ve üstbilişsel farkındalıklarına etkisini incelediklerinde, STEM etkinlikleri 
sonucunda fene yönelik motivasyonlarda olumlu yönde bir etkiye sahip olduğu sonucuna ulaşmışlardır.

Yıldırım ve arkadaşları (2017), ise STEM uygulamaları ve tam öğrenmenin öğrencilerin akademik başarılarına fene yönelik sorgulayıcı öğrenme, motivasyon ve STEM'e yönelik tutumlarına etkisini araştırmıştır. Araştırma sonucunda STEM uygulamaları ve tam öğrenmenin modeli ile sunulmasının öğrenilen bilgilerin kalıcılığı üzerinde olumlu etkiye sahip olduğu, sadece STEM uygulamalarının ise fene yönelik motivasyon ve sorgulayıcı öğrenme becerileri üzerinde olumlu etki yapmadığ 1 tespit edilmiştir.

Uğraş (2018), STEM etkinliklerinin öğrencilerin STEM'e ilişkin tutumları, bilimsel yaratıcılıkları, motivasyon inançları üzerindeki etkileri ve STEM eğitimine ilişkin görüşlerini incelediğinde, araştırmaya katılan öğrencilerin etkinliklerin uygulanmasından sonra motivasyon inançlarında anlamlı bir farklılık olduğu sonucuna ulaşmıştır. Araştırmacı öğrencilerin motivasyon inançlarının artması ile eğitim sürecine aktif bir şekilde katılım, fikirler ve ürünler geliştirme boyutlarında doğru orantılı bir ilişki olduğu sonucuna ulaşmıştır.

Araştırmada elde edilen bulgular incelendiğinde STEM eğitiminin öğrencilerin fen öğrenmeye yönelik motivasyonunu genel olarak olumlu etkilediği, alt boyutlarda ise sadece araştırma yapma ve katılım sağlama boyutlarında olumlu bir etki gösterdiği sonucuna ulaşılmıştır. Ön-test sonuçlarının iletişim, araştırma yapma, performans ve katılıma yönelik boyutlarda yüksek olmasından okulun yapılandırmacı yaklaşım temel alınarak uygulanan 5E modelinin olumlu etki sağladığı çıkarımı yapılabilir. Dewey (1859-1952), Kilpatrick (18711965), Kerschensteiner (1854-1932), Decroly (1871-1932), Ferriere (1879-1960), Freinet (18961966), Gaudig (1860-1923) gibi önde gelen temsilcilerin olduğu iş eğitimi yaklaşımlarında, yapılandırmacılık yaklaşımı, proje tabanlı öğrenme yaklaşımlarının özelliklerinin STEM eğitim yaklaşımıyla paralel olduğunu görebiliriz. Bu yaklaşımlarda öğrencinin öğrenirken aktif olması yani yaparak yaşayarak öğrenme prensibinin öğrencinin zihinsel becerilerini geliştireceği anlayışını vardır. Özellikle Yıldırım ve arkadaşlarının 2017 yılında yaptığı çalışmada elde ettiği sonuç bu bulguları destekler niteliktedir. STEM eğitimi sonrasında fen öğrenmeye yönelik işbirliği motivasyonunu düşme grup çalışmaları ve işbirlikli öğrenme stratejilerinin yeterli düzeyle kullanılmadığını göstermektedir. İşbirliği boyutunun düşük olmasından, çalışmaların bireysel teknoloji kullanımın boyutunun ağırlıkta olduğu bir proje süreci yürütüldüğü çıkarımına ulaşılabilir. Eğitim etkinliklerinde grup çalışmalarının destekleyici çalışmalara ağırlık verilmesi sağlanmalıdır. Öğretmenlerin çoklu disiplin anlayışı ve proje geliştirme süreçleri hakkında mesleki yeterlilikleri geliştirilmelidir. Sağlıklı ve çok yönlü beceri gelişimi için eğitim sürecinin matematik, fen, teknoloji ve mühendislik alt boyutlarının tamamını destekleyen etkinlikleri içermesi gerekmektedir.

Sonuç olarak, yapılan araştırmada elde edilen bulgular ve ilgili araştırmalar incelendiğinde aşağı da belirtilen sonuçlara ulaşılmıştır.

a) STEM eğitiminin STEM alt alanlarından fen, mühendislik, matematik teknolojiye karşı tutumuna etkisinde anlamlı olarak değişim gözlenmemiştir.

b) STEM eğitiminin öğrencilerin genel olarak tüm STEM alanlarına karşı tutumuna etkisi anlamlı olarak değişim gözlenmemiştir. 
c) STEM eğitimi öğrencilerin araştırmaya ve katılıma yönelik motivasyonu üzerinde olumlu etkiye sahipken işbirlikli çalışmaya, iletişim, performansa yönelik motivasyon STEM eğitimi sonrasında anlamlı olarak değişmemektedir.

d) STEM eğitimi sonrasında genel olarak fen öğrenmeye yönelik motivasyonun anlamlı olarak arttığı gözlenmiştir.

Bu sonuçlar incelendiğinde ise aşağıdaki öneriler sunulmuştur.

a) STEM etkinlikleri incelendiğinde teknoloji alanının ağırlık kazandığı görülmüştür. STEM eğitim uygulamalarının geliştirilmesinde öğrenci merkezli öğrenme süreçlerini barındıran yapılandırmacı yaklaşım temelli planlamalar yapılmalı ve Eğitim sürecinin sağlıklı uygulanması için matematik, fen, teknoloji ve mühendislik alt boyutlarının tamamını destekleyen bütüncül etkinlik planlamaları yapılmalıdır.

b) Öğretmenlerin çoklu disiplin anlayışı ve proje geliştirme süreçleri hakkında mesleki yeterlilikleri geliştirilmeli ve STEM eğitimini uygulayan öğretmenlerin STEM'in alt disiplinlerine hakimiyetinin sağlanması için ilgili disiplinlerde uzman öğretmenlerle ortak çalışmalar yürütmelidir.

c) Araştırmada Fen öğrenmeye yönelik işbirliği motivasyonun düşük olduğu sonucuna ulaşılmıştı bu nedenle eğitim etkinliklerinde grup çalışmalarının destekleyici çalışmalara ağırlık verilmesi sağlanmalıdır.

\section{Teşekkür ve Bilgilendirme}

Bu çalışma Prof. Dr. Demet Somuncuoğlu ÖZERBAŞ danışmanlığında Mustafa Şanlı'nın Gazi Üniversitesi Eğitim Bilimleri Enstitüsünde “STEM Eğitim Uygulamalarının Öğrencilerin STEM Alanlarına Yönelik Tutumları ve Fen Öğrenme Motivasyonlarına Etkisi” isimli yüksek lisans tezinden üretilmiştir

\section{Kaynakça}

Akbaba, S. (2006). Eğitimde motivasyon. Kazım Karabekir Eğitim Fakültesi Dergisi, 13, 343-361.

Akgündüz, D., Aydeniz, M., Çakmakçı, G., Çavaş, B., Çorlu, M. S., Öner, T., \& Özdemir, S. (2015). STEM Eğitimi Türkiye Raporu "Günün Modası mı Yoksa Gereksinim mi?". İstanbul: İstanbul Aydın Üniversitesi.

https://www.researchgate.net/publication/281098450_STEM_egitimi_Turkiye_raporu_Gunun_mod asi_mi_yoksa_gereksinim_mi_A_report_on_STEM_Education_in_Turkey_A_provisional_agenda_ or_a_necessityWhite_Paper sayfasından erişilmiştir.

Bakırcı, H. ve Kutlu, E. (2018). Fen bilimleri öğretmenlerinin FeTeMM yaklaşımı hakkındaki görüşlerinin belirlenmesi. Türk Bilgisayar ve Matematik Eğitimi Dergisi, 9(2), 367-389.

Başaran, İ.E. (1990). Eğitim psikolojisi: Modern eğitimin psikolojik temelleri, Ankara: Gül Yayınevi.

Buyruk, B. ve Korkmaz, Ö. (2016). FeTeMM farkındalık ölçeği (FFÖ): Geçerlik ve güvenirlik çalışması. Part B: Türk Fen Eğitimi Dergisi, 3(2), 61-76.

Bybee, R. W. (2010). What is STEM education? Science, 329, 996. http://dx.doi.org/ 10.1126/science. 1194998

Creswell, J. W., \& Clark, V. L. P. (2017). Designing and conducting mixed methods research. Oaks, Sage. 
Çorlu, M. S. \& Çallı, E. (2017). STEM Kuram ve Uygulamaları. İstanbul: Pusula

D'Andrade, R. G. (1992). Schemas and motivation. Human motives and cultural models, 23, 44.

Dede, Y \& Yaman, S . (2008). Fen öğrenmeye yönelik motivasyon ölçeği: Geçerlik ve güvenirlik çalışması. Necatibey Eğitim Fakültesi Elektronik Fen ve Matematik Eğitimi Dergisi, 2 (1), 19 - 37. https://dergipark.org.tr/tr/pub/balikesirnef/issue/3366/46483 sayfasından erişilmiştir.

Eroğlu, S. \& Bektaş, O . (2016). STEM eğitimi almış fen bilimleri öğretmenlerinin STEM temelli ders etkinlikleri hakkındaki görüşleri. Eğitimde Nitel Araştırmalar Dergisi, 4 (3), 43-67. https://dergipark.org.tr/tr/pub/enad/issue/32043/356762 sayfasından erişilmiştir.

Feldman, R.S. (1993). Understanding psychology. McGraw-Hill Inc, New York

Kağıtçıbaşı, Ç. (1985). İnsan ve insanlar. İstanbul: Sermet Matbaası.

Karasar, N. (2013). Bilimsel Araştırma Yöntemi, Ankara: Nobel.

Kargı, S. (2019). Ortaokul Öğrencilerinin STEM eğitimine yönelik tutum ölçeği, Uluslararası Billimsel Araştırmalar Kongresi'nde sunulmuş bildiri, UBAK, Yalova

Keser,H (1987). İş eğitimi için geliştirilmiş bir proje örneği. Ankara Üniversitesi Eğitim Bilimleri Fakültesi Dergisi, 20, 1. DOI: 10.1501/Egifak_0000001061.

Koştur, H. İ. (2017). FeTeMM eğitiminde bilim tarihi uygulamaları. Başkent Üniversitesi

Eğitim Dergisi. 4(1), 61-73.

Intel® Teach Program (2014). Assessing projects and 21st century skills. https://www.intel.com/content/dam/www/program/education/us/en/documents/assessingprojects/overview-and-benefits/21st-century-skills.pdf sayfasından erişilmiştir.

MEB (2018). İlköğretim fen bilimleri dersi öğretim programı (ilkokul ve ortaokul 3, 4, 5, 6, 7 ve 8. sınıflar). Talim ve Terbiye Kurulu Başkanlığı, Ankara. ttkb.gov.tr sayfasından erişilmiştir.

Özden, Y. (2005). Okulu Yeniden Kurmak. Ankara: Nobel.

Şahin, A., Ayar, M. C., \& Adıgüzel, T. (2014). STEM related after-school program activities and associated outcomes on student learning. Educational Sciences: Theory and Practice, 14(1), 309-322. https://www.researchgate.net/publication/265503786_STEM_Related_After-

School_Program_Activities_and_Associated_Outcomes_on_Student_Learning sayfasindan erişilmiştir.

Tüysüz, M., Öztürk, G., Geban, Ö, \& Bektaş, O. (2018). Fen bilimleri öğretmenlerinin ve öğretmen adaylarının fizik, kimya ve biyoloji disiplinlerinin entegrasyonuna ilişkin görüşleri. International $\begin{array}{lllll}\text { Online Journal of } & \text { 130-145. }\end{array}$ http://www.iojes.net/DergiTamDetay.aspx?ID=30\&Detay=Ozet sayfasından erişilmiştir.

Uğraş, M. (2018). The effects of STEM activities on STEM attitudes, scientific creativity and motivation beliefs of the students and their views on STEM education. International Online Journal of Educational Sciences, 10 (5), 165-182.

Yamak, H., Bulut, N. \& Dündar, S . (2014). 5. sınıf öğrencilerinin bilimsel süreç becerileri ile fene karşı tutumlarına FeTeMM etkinliklerinin etkisi. Gazi Üniversitesi Gazi Eğitim Fakültesi Dergisi, 34 (2), 249-265. http://dx.doi.org/10.17152/gefd.15192

Yıldırım, B. \& Altun, Y. (2015). STEM eğitim ve mühendislik uygulamalarının fen bilgisi aboratuvar dersindeki etkilerinin incelenmesi. El-Cezerî Fen ve Mühendislik Dergisi. 2(2), 28-40.

Yıldırım, B. \& Selvi, M. (2017). STEM uygulamaları ve tam öğrenmenin etkileri üzerine deneysel bir çalışma. Eğitimde Kuram ve Uygulama, 13(2), 183-210. 